\title{
PEMBUATAN PRODUK MULTIMEDIA SEBAGAI MEDIA INFORMASI DAN DOKUMENTASI PERTANIAN DI BALAI BESAR PENGKAJIAN DAN PENGEMBANGAN TEKNOLOGI PERTANIAN
}

\section{Creating Multimedia Products as Agricultural Information and Documentation Media at the Indonesian Center for Agricultural Technology Assessment and Development}

\author{
NITA QONITAH DESY AYU SARI ${ }^{1}$, AEP SETIAWAN ${ }^{2}$, ELYA NURWULLAN $^{3}$ \\ ${ }^{1}$ Sekolah Vokasi Institut Pertanian Bogor, Jalan Kumbang 14, Bogor \\ 2 Sekolah Vokasi Institut Pertanian Bogor, Jalan Kumbang 14, Bogor \\ ${ }^{3}$ Balai Besar Pengkajian dan Pengembangan Teknologi Pertanian, Jalan Tentara Pelajar, \\ Cimanggu 10, Ciwaringin, Bogor \\ Email : $\frac{1 \text { qonitahnita35@gmail.com, } 2 \text { aep.setiawan41@gmail.com, }}{\text { [elyaelya72@gmail.com }}$
}

\begin{abstract}
The Indonesian Center for Agricultural Technology Assessment and Development (BBP2TP) is a Research, study and development center for agricultural technology that houses 31 Agricultural Technology Assessment Centers (BPTP) in regions that produce location-specific agricultural technology. BBP2TP is a means to convey information about agricultural products from farmers, researchers and extension workers to the public by using electronic media in the form of news, articles, powerpoint slides and printed media in the form of brochures and books in terms of providing information and documentation. Based on this, several multimedia products were made such as posters, video tutorials, and video documentation of activities.

The method used in making this multimedia product was made according to what was done during the Field Work Practices (PKL) at BBP2TP both when working on posters, video tutorials and video documentation of activities. There are four stages: observation, data collection, editing, and testing.
\end{abstract}

Keywords: BBP2TP, documentation, information, multimedia, posters, videos

\section{ABSTRAK}

Balai Besar Pengkajian dan Pengembangan Teknologi Pertanian (BBP2TP) adalah Balai penelitian, pengkajian dan pengembangan teknologi pertanian yang menaungi 31 Balai Pengkajian Teknologi Pertanian (BPTP) di daerah yang menghasilkan teknologi pertanian spesifik lokasi. BBP2TP menjadi sarana untuk menyampaikan informasi tentang produk pertanian dari petani, peneliti dan penyuluh kepada masyarakat dengan menggunakan media elektronik berupa berita, artikel, slide powerpoint dan media cetak berupa brosur dan buku dalam hal pemberian informasi dan dokumentasi. Berdasarkan hal tersebut, maka dibuatlah beberapa produk multimedia seperti poster, video 
tutorial, dan video dokumentasi kegiatan.

Metode yang digunakan dalam pembuatan produk multimedia ini dibuat sesuai dengan apa yang dilakukan saat Praktik Kerja Lapang (PKL) di BBP2TP baik saat mengerjakan poster, video tutorial maupun video dokumentasi kegiatan. Terdapat empat tahapan yaitu observasi, pengumpulan data, proses penyuntingan, dan pengujian.

Kata kunci: BBP2TP, dokumentasi, informasi, multimedia, poster, video

\section{PENDAHULUAN}

Balai Besar Pengkajian dan Pengembangan Teknologi Pertanian (BBP2TP) adalah Unit Pelaksana Teknis (UPT) dibidang pengkajian dan pengembangan teknologi pertanian yang berada di bawah dan bertanggung jawab kepada Kepala Badan Litbang Pertanain. BBP2TP menaungi 31 Balai Pengkajian Teknologi Pertanian (BPTP) di daerah yang menghasilkan teknologi pertanian spesifik lokasi.

Kementerian Pertanian sejak tahun 2018, telah meluncurkan program Bedah Kemiskinan Rakyat Sejahtera (BEKERJA) dengan salah satu program aksi utamanya memberikan bantuan 50 ekor ayam lokal jenis KUB (Kampung Unggul Balitbangtan) yang berumur satu hari atau Day Old Chicken (DOC) untuk setiap rumah tangga miskin (RTM). Ayam KUB merupakan ayam kampung hasil seleksi genetik yang memiliki keunggulan antara lain, mampu bertelur hingga mencapai 160-180 butir/ekor/tahun, masa mengeram berkurang hingga tinggal $10 \%$ sehingga ayam cepat bertelur kembali. Selain itu, ayam ini dapat tumbuh lebih cepat daripada ayam kampung biasa. Rasa daging ayam KUB gurih, sebagaimana ayam kampung pada umumnya.Untuk menjamin adopsi inovasi sesuai anjuran serta keberlanjutan usaha, dilakukan pendampingan oleh para pendamping desa dan tim BEKERJA yaitu BBP2TP. Pendampingan yang dilakukan berupa pelatihan atau workshop dengan bantuan buku panduan dan slide power point.

BBP2TP menjadi salah satu instansi pemerintahan yang menggunakan media elektronik dan media cetak dalam hal pemberian informasi dan dokumentasi. Hal ini menjadi sarana untuk menyampaikan inovasi tentang program kerja dan produk pertanian dari petani, peneliti dan penyuluh kepada masyarakat. Sehingga, masyarakat mengetahui perkembangan pertanian di Indonesia. Beberapa media elektronik yang digunakan BBP2TP adalah situs website, media sosial Facebook, Instagram, Twitter, dan Youtube, serta media cetak yang digunakan BBP2TP adalah brosur dan buku.

Pada saat ini, informasi yang disuguhkan kepada masyarakat hanya berbentuk gambar dan teks, maka diperlukan inovasi dalam menyampaikan informasi dan dokumentasi berupa desain grafis dan videografi yang informatif agar masyarakat lebih tertarik untuk menyimak setiap pembahasan yang diberikan. Berdasarkan latar belakang yang telah diuraikan di atas, maka judul yang dipilih untuk tugas akhir ini adalah Pembuatan Produk Multimedia Sebagai Media Informasi dan Dokumentasi Pertanian di Balai Besar Pengkajian dan Pengembangan Teknologi Pertanian. Melalui pembuatan tugas akhir ini 
diharapkan hasil karya desain grafis dan videografi yang telah dibuat dapat memberikan gaya pembaharuan dalam hal publikasi informasi dan dokumentasi di BBP2TP.

Tujuan dari Pembuatan Produk Multimedia Sebagai Media Informasi dan Dokumentasi Pertanian di BBP2TP adalah untuk membuat desain poster lomba foto dan video program kerja Kementerian Pertanian dengan tema Bangga Pertanian Daerahku Maju, membuat video pembelajaran untuk program BEKERJA yaitu tutorial persiapan yang harus dilakukan ketika ayam Kampung Unggul Balitbangtan (KUB) Day Old Chicken (DOC) akan datang, dan membuat video dokumentasi dan testimoni kegiatan program BEKERJA mengenai respons masyarakat Desa Bayalangu Kidul, Kabupaten Cirebon terhadap video tutorial persiapan yang harus dilakukan ketika ayam KUB DOC akan datang.

\section{METODE PENELITIAN}

Media informasi yang telah dibuat selama masa Praktik Kerja Lapangan (PKL) di BBP2TP sebanyak tiga produk multimedia yaitu 1 desain grafis, 1 video tutorial, dan 1 video dokumenter. Semua karya yang dibuat melalui empat tahap yaitu observasi, pengumpulan data, proses penyuntingan, proses demonstrasi dan pengujian.
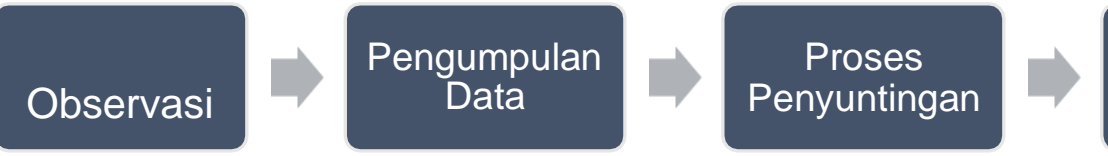

Pengujian

Gambar 1 Metode bidang kajian

\section{Observasi}

Tahap pertama dalam pembuatan produk multimedia adalah observasi. Menurut KBBI, observasi adalah peninjauan secara cermat, sebelum praktik mengajar, para calon guru mengadakan kegiatan ke sekolah-sekolah. Tahap ini dilakukan untuk mengetahui latar belakang atau permasalahan dari pembuatan produk multimedia, menentukan target audience berdasarkan latar belakang, serta menentukan jenis dan sumber data yang dapat digunakan dalam tahap pengumpulan data.

\section{Pengumpulan Data}

Tahap kedua adalah pengumpulan data yang meliputi pencarian referensi dan diskusi dengan klien untuk mendapat ide dan konsep yang sesuai dengan keinginan klien agar tidak melenceng dari yang seharusnya. Pada tahap pembuatan video diperlukan storyline, pengumpulan bahan berupa stockshoot video dan informasi hasil pengumpulan data. Pembuatan storyline diperlukan sebagai alat bantu dalam tahap proses penyuntingan dan dapat memberikan gambaran kepada klien mengenai video yang akan dibuat. 


\section{Proses Penyuntingan}

Tahap ketiga adalah proses penyuntingan yang berisi proses pembuatan desain grafis dan videografi dengan menggabungkan bahan-bahan yang telah dikumpulkan pada tahap sebelumnya, diperlukan software atau perangkat lunak dalam pembuatannya yaitu Adobe Illustrator CC 2018, Adobe Photoshop CS5, Adobe Premiere Pro CC 2018 dan Adobe Audition CC 2018.

\section{Pengujian}

Tahap terakhir adalah pengujian, setelah menyelesaikan pembuatan desain grafis dan video maka dapat dilakukan proses demonstrasi, pemberian saran dan pendapat dari klien. Saran dan pendapat menjadi revisi bagi pembuat karya dan apabila revisi telah diselesaikan maka karya dapat dipublikasikan. Menurut KBBI, revisi adalah peninjauan (pemeriksaan) kembali untuk perbaikan.

\section{HASIL DAN PEMBAHASAN}

\section{Hasil dan Pembahasan Desain Grafis}

Desain grafis adalah satu bentuk komunikasi yang memanfaatkan elemen visual seperti bentuk, foto, tulisan, dan elemen lainnya. Tujuannya adalah untuk menyampaikan ide atau gagasan ke orang lain menggunakan elemen-elemen tersebut (Enterprise 2018).

\section{Observasi}

Poster ini berisi penjelasan kegiatan yang mengajak anak muda Indonesia atau generasi milenial untuk mendukung pembangunan pertanian di Indonesia. Maka, dibuatlah suatu lomba untuk mendukung kegiatan ini sebagai bukti partisipasi generasi milenial terhadap keberhasilan pembangunan pertanian di daerah masing-masing. Jenis lomba yang diadakan adalah lomba foto dan video bertema Bangga Pertanian Daerahku Maju, dilampirkan juga hadiah sebagai apresiasi kepada pemenang, syarat-syarat, ketentuan lomba, dan waktu pengumpulan karya.

\section{- Target Audience}

Target audience yang ditentukan yaitu pelajar dan masyarakat umum dengan syarat usia 15-24 tahun.

\section{- Jenis dan Sumber Data}

Jenis data yang digunakan adalah data primer dan sekunder. Data primer yaitu data yang diambil dari sumber pertama di lapangan dalam bentuk wawancara dengan orang yang benar-benar mengetahui informasinya. Data sekunder adalah data yang diperoleh dari sumber kedua seperti brosur, buku, dan sebagainya (Lexi 2009). Maka untuk sumber data pembuatan desain grafis didapatkan langsung dari pembimbing lapang PKL yaitu deskripsi kegiatan berupa file word, foto Menteri Pertanian Bapak Amran Sulaiman, logo Kementerian Pertanian, dan logo Agro Inovasi. Beberapa data seperti foto dan logo-logo ditunjukkan pada Gambar 2. 

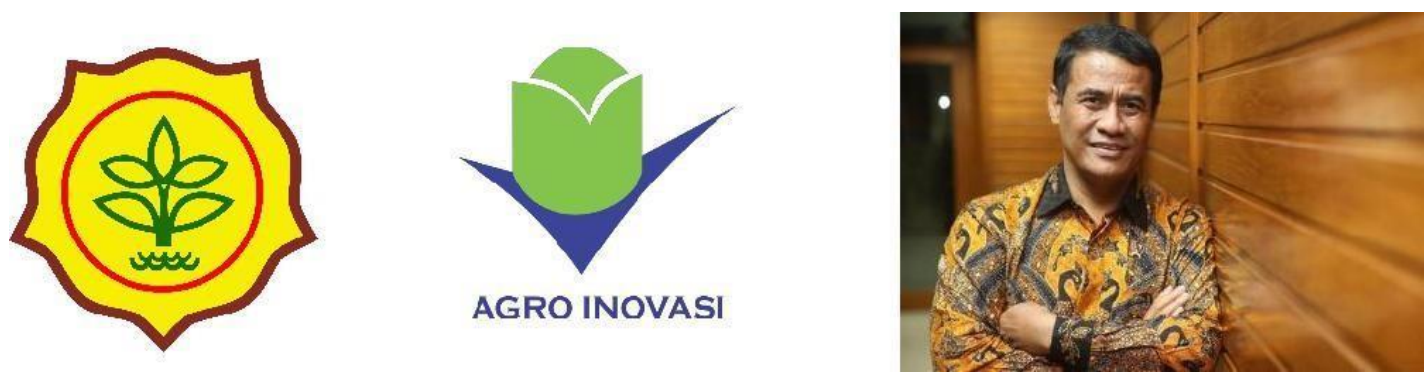

Gambar 2 Data gambar yang diberikan oleh BBP2TP

\section{Pengumpulan Data}

\section{- Pencarian Referensi}

Referensi didapatkan dari hasil pencarian di internet. Referensi-referensi yang didapatkan menjadi bahan perbandingan tersendiri dalam pembuatan poster. Contohnya dapat dilihat pada Gambar 3.
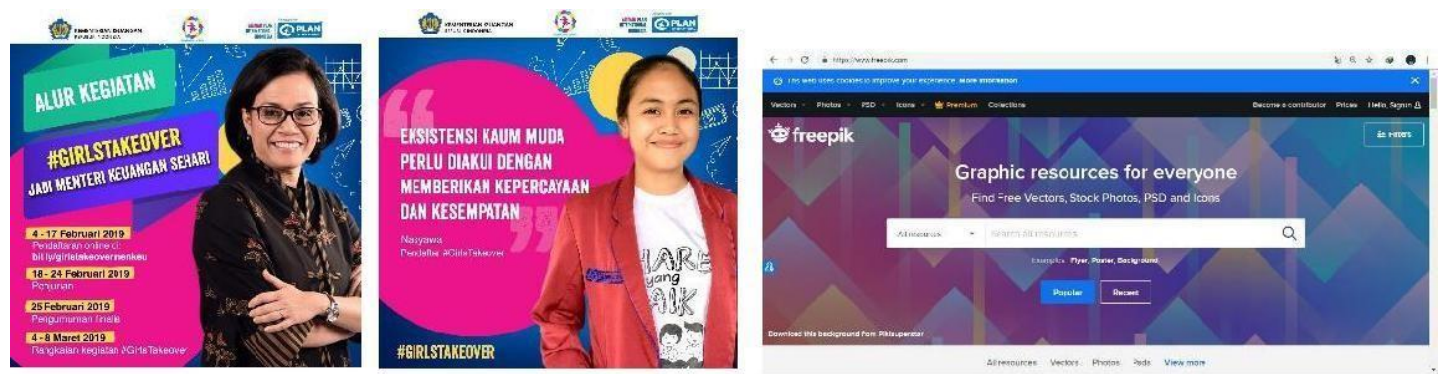

Gambar 3 Referensi dalam pengumpulan data

\section{- Perancangan Konsep}

Proses perancangan konsep pada pembuatan desain grafis didiskusikan bersama pembimbing lapang, setelah itu didapatkan hasil yang diinginkan yaitu warna, isi dan ukuran yang dibutuhkan untuk publikasi di sosial media terutama instagram dan isi yang akan disampaikan.

\section{- Pengumpulan Bahan}

Bahan yang diperlukan adalah typeface, stockshoot foto dan vector.

\section{Proses Penyuntingan}

Semua bahan yang telah dikumpulkan, kemudian dirancang dengan menggunakan software yang telah ditentukan berdasarkan konsep yang telah didiskusikan yaitu ukuran poster, warna, dan isi.

\section{- Menentukan ukuran poster}

Ukuran yang dibutuhkan untuk publikasi pada sosial media khususnya instagram yaitu persegi/square 852 (width) x 851 (height) pixels dengan resolusi 72 dpi (dotper inch) agar kualitas poster yang dihasil tinggi atau tidak pecah saat publikasi kesosial media instagram.

- Menentukan warna

Warna utama yang dipilih mengacu kepada logo Kementerian Pertanian 
yaitu warna hijau dengan kode heksa \#279157 dan warna kuning dengan kode heksa \#F2EC1A.

\section{- Menentukan bahan dan isi}

Penulisan isi dalam poster tersebut menggunakan typeface jenis sans serif (tanpa kait). Typeface adalah rancangan karakter dari sekumpulan huruf yang memiliki karakteristik sehingga membedakannya dengan jenis kumpulan huruf yang lain. Typeface yang digunakan pada pembuatan poster adalah muro, dan google product sans. Muro digunakan sebagai penulisan judul poster, dan nama menteri pertanian untuk memberikan kesan tegas.

\section{Pengujian}

Poster yang telah dibuat diajukan kepada pembimbing lapang PKL untuk mendapatkan saran dan masukan. Revisi yang didapatkan berupa saran penambahan informasi terkait tema lomba yang diletakkan di samping kiri foto dan penulisan total hadiah di samping kanan foto.

\section{Hasil dan Pembahasan Video Tutorial Persiapan yang Harus Dilakukan Ketika Ayam KUB DOC Akan Datang}

Video tutorial yang dibuat merupakan video pembelajaran untuk mendukung rangkaian kegiatan program BEKERJA Kementerian Pertanian antara lain pelatihan kepada masyarakat, dan bimbingan teknis berbentuk tayangan video.

\section{Observasi}

\section{- Target Audience}

Target audience ditunjukkan untuk masyarakat umum dengan syarat usia 18-60 tahun, hal ini dilakukan karena masyarakat dengan rentang usia di atas masih dapat melihat dan mendengar dengan baik.

\section{- Jenis dan Sumber Data}

Jenis data yang digunakan dalam proses pembuatan video tersebut adalah data primer dan sekunder. Data primer yang didapatkan yaitu hasil wawancara langsung dengan Bapak Dedi Muslih selaku Peneliti di Balai Penelitian Ternak (Balitnak) yang beralamat di Jl. Veteran III, Ciawi, Bogor, sedangkan data sekunder yang didapatkan berasal dari buku saku program BEKERJA yang dibuat oleh tim Penyuluh BBP2TP.

\section{Pengumpulan Data}

\section{- Pencarian Referensi}

Referensi video didapatkan dari hasil pencarian di youtube, untuk mempermudah pencarian maka menggunakan kata kunci "Ayam KUB", "Guide To Raising Chickens" dan referensi musik didapatkan dari website penyedia musik seperti audiojungle, kata kunci dalam pencariannya "Inspiring Corporate Backsound", hal ini dilakukan untuk memberikan kesan mengajak kepada 
masyarakat agar menonton video tersebut sampai akhir.

\section{- Perancangan Konsep}

Proses perancangan konsep pada pembuatan video tutorial didiskusikan bersama pembimbing lapang, dan Penyuluh BBP2TP. Setelah itu didapatkan hasil yang diinginkan yaitu pembuatan storyline untuk menentukan jalan cerita dari video yang akan dibuat. Pada storyline pembuatan video tutorial ini, berisi alur tata cara mempersiapkan alat dan bahan sederhana yang akan diperagakan secara bertahap dengan bantuan penjelasan oleh narasumber.

\section{- Pengumpulan Bahan}

Bahan yang diperlukan adalah stockshoot dan footage video yang berisi informasi dari sumber data. Proses pengambilan gambar ini dilakukan di luar ruangan, kendala yang dihadapi adalah waktu terkait pendistribusian ayam KUB DOC yang tidak menentu, cuaca, dan suasana sekitar yang berubah-ubah, sehingga berdampak buruk terhadap pencahayaan dan audio yang dihasilkan. Beberapa teknik pengambilan gambar yang digunakan dapat dilihat pada Tabel 1.

Tabel 1 Teknik pengambilan gambar video tutorial

\begin{tabular}{lll}
\hline No & Adegan & Keterangan \\
\hline
\end{tabular}

Kandang sederhana penempatan ayam

KUB untuk didistribusikan ke berbagai daerah. Tipe ukuran pengambilan gambar : Full Shot Sudut pandang kamera : Eye level. Pergerakan kamera : -

2

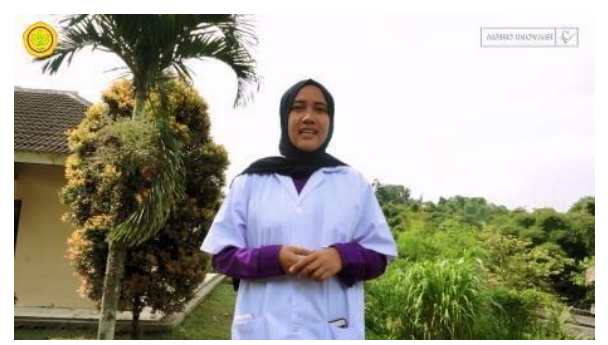

Narator atau MC memberi kalimat sambutan dan pengantar

Tipe ukuran pengambilan gambar

: Medium shoot

Sudut pandang kamera : Eye level

Pergerakan kamera : -

\section{Proses Penyuntingan}

Semua bahan yang telah dikumpulkan, kemudian dirancang dengan menggunakan software Adobe Premiere Pro CC 2018 untuk gambar dan Adobe Audition untuk suara. Proses penggabungan ini disesuaikan berdasarkan storyline yang telah dibuat. 


\section{- Menentukan Ukuran Video}

Video yang dibuat berukuran 720 pixels (height) x 1280 pixels (wide) vertical 16:9 dengan 59.94 frame per second (fps) menyesuaikan pengaturan kamera, agar video yang dihasilkan tetap berkualitas tinggi tetapi memiliki ukuran data yang kecil.

\section{- Mengimpor file}

Tahap berikutnya adalah mengimpor file footage (potongan video yang akan diedit), selain potongan video, audio, teks, gambar, dan efek khusus juga dapat disertakan sebagai pendukung (Enterprise 2019). Penulis mengimpor file logo Kementerian Pertanian dan Agro Inovasi dengan format png sebagai identitas dari video tersebut, serta video outro yang dibuat oleh Penyuluh BBP2TP sebagai penutup dari video. Menambahkan template intro yang dibuat dengan Adobe Premiere Pro dan menambahkan audio instrumental untuk intro dan musik yaitu Inspiring Corporate Backsound yang sudah didapat pada tahap pengumpulan data.

\section{- Menambahkan efek khusus}

Pilihan efek khusus yang digunakan adalah lumetri color dan video transition. Pembuatan video tutorial ini hanya dilakukan color correction karena menjaga warna asli dan tema dari video tersebut. Proses ini akan membuat kualitas gambar dari segi cahaya maupun warna gambar agar terlihat lebih baik. Transisi yang digunakan yaitu Cross Dissolve, Dip To Black, dan Film Dissolve.

\section{- Menambahkan teks}

Penulis membuat intro sebagai judul video dan keterangan tambahan sebagai penjelas informasi dengan menggunakan template yang tersedia dari menu essential graphic Adobe Premiere Pro CC 2018. Typeface yang digunakan untuk judul yaitu gotham. Sedangkan, typeface untuk keterangan tambahan yaitu bebas.

\section{- Menyunting audio}

Penyuntingan audio dapat dilakukan dengan Adobe Premiere Pro dan Adobe Audition, salah satu kendala yang ada yaitu suara bising/noise yang berasal dari kendaraan, angin, dan lain-lain. Fitur yang dapat digunakan untuk mengurangi kendala tersebut adalah noise reduction. Setelah dilakukan penyuntingan audio pada Adobe Audition, selanjutnya penggabungan dengan backsound yang dilakukan pada Adobe Premiere Pro. Proses ini mengatur keyframe pada backsound, sehingga ketika suara orang berbicara, maka desibel keyframe pada backsound akan turun. Jadi tidak bertabrakan/saling meredam satu sama lain. Fitur yang digunakan untuk mengatur keyframenya yaitu essential sound.

\section{- Rendering/Export}

Proses render video ini menghasilkan output video berdurasi 2 menit 50 detik dengan resolusi 1280 × 720 pixel dan format mp4.

\section{Pengujian}

Pada tahap pengujian, hasil karya diperiksa kembali oleh pembimbing 
lapang dan Penyuluh BBP2TP dalam bentuk presentasi yang bertujuan agar video yang telah dibuat sesuai dengan materi. Tidak ada revisi masalah video ini, hanya ada diskusi pendapat dan saran untuk judul video, tetapi akhirnya tetap dengan judul ini.

\section{Hasil dan Pembahasan Video Dokumenter dan Testimoni Kegiatan Program BEKERJA}

Video dokumenter dan testimoni kegiatan Program BEKERJA berisi cuplikan rangkaian kegiatan dari awal hingga akhir, dalam video ini juga terdapat testimoni dan respons masyarakat Desa Bayalangu Kidul, Kabupaten Cirebon terhadap video tutorial yang sudah dibuat sebelumnya yaitu video tutorial persiapan yang harus dilakukan ketika ayam KUB DOC akan datang.

\section{Observasi}

Pelaksanaan program BEKERJA Kabupaten Cirebon dilaksanakan pada 25-30 Maret 2019 yang terdiri atas 3 rangkaian kegiatan, pertama pelatihan pendamping desa atau taining of trainers, kedua bimbingan teknis kepada seluruh RTM, dan ketiga pembagian peralatan kandang serta pembagian ayam KUB DOC. Kegitan ini memerlukan dokumentasi yang digunakan sebagai laporan perjalanan dan pertanggungjawaban kegiatan, maka dari itu dibuatlah sebuah video dokumentasi kegiatan sebagai pendukung laporan pertanggungjawaban tertulis.

\section{- Target Audience}

Target audience video ini ditunjukkan kepada masyarakat umum dengan syarat usia 18-60 tahun, hal ini dilakukan karena masyarakat dengan rentang usia di atas masih dapat melihat dan mendengar dengan baik.

\section{- Jenis dan Sumber Data}

Jenis data yang digunakan dalam proses pembuatan video tersebut adalah data primer. Data primer yang didapatkan yaitu hasil diskusi langsung mengenai jadwal kegiatan atau rundown dengan Bapak Bachtar Bakrie selaku penanggung jawab dan pegawai BBP2TP sebagai tim program BEKERJA Kabupaten Cirebon. Data juga didapatkan dari wawancara via telepon dengan Bapak Dodi selaku Kepala Desa Bayalangu Kidul terkait persiapan dan penggambaran lokasi kegiatan.

\section{Pengumpulan Data}

\section{- Pencarian Referensi}

Referensi video didapatkan dari youtube Kementerian Pertanian RI dengan judul video "Sorgum, Mutiara Darat dari Pesisir Timur Flores". Referensi musik didapatkan dari youtube dan website penyedia musik seperti audiojungle, penulis menggunakan musik instrument cinematic inspiration dan intrumental musik daerah hal ini dilakukan karena cocok menggambarkan susana kegiatan yang sedang terjadi dan lokasi kegiatan. Kata kunci dalam pencarian dalam youtube yaitu "Instrumen jawa barat", sedangkan pencarian dalam audiojungle 
yaitu "Indonesia" dan "Cinematic Inspiring Backsound". Penulis juga mencari referensi tampilan warna atau look yang akan digunakan saat proses penyuntingan video.

\section{- Perancangan Konsep}

Proses perancangan konsep pada pembuatan video dokumenter dan testimoni ini tidak menggunakan storyline seperti pada video tutorial, dikarenakan video ini bersifat dokumentasi kegiatan yang penulis sendiri belum mengetahui kondisi di lapangan. Sehingga perencanaan konsep video baru dilaksanakan setelah satu minggu kegiatan berlangsung, hasil konsep yang penulis dapatkan yaitu cinematic story telling. Cinematic Story Tellling adalah teknik menggambarkan suatu kegiatan atau cerita mengikuti irama musik dan alur kegiatan karena mampu menarik emosi penonton untuk lebih menjiwai video tersebut.

\section{- Pengumpulan Bahan}

Pengumpulan bahan dilaksanakan selama enam hari mulai tanggal 25 30 Maret 2019 meliputi pengambilan gambar dan rekaman suara calon narasumber yaitu masyarakat Desa Bayalangu Kidul yang dipilih secara acak oleh penulis. Rekaman suara diambil melalui smartphone sebagai mic external. Teknik Pengambilan gambar yang dilakukan ada 3 jenis, ukuran pengambilan gambar, sudut pandang, dan pergerakan kamera (Bonafix 2011). Beberapa teknik pengambilan gambar dalam video dokumenter dan testimoni dapat dilihat pada Tabel 2.

Tabel 2 Teknik pengambilan gambar video dokumenter dan testimoni

\begin{tabular}{|c|c|c|}
\hline No & Adegan & Keterangan \\
\hline 1 & 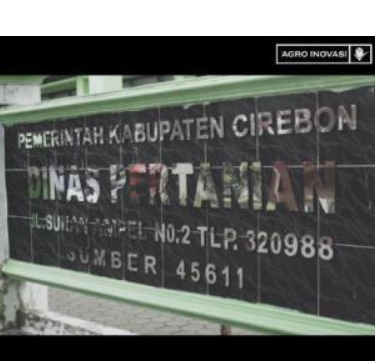 & $\begin{array}{l}\text { Memperlihatkan lokasi rapat } \\
\text { persiapan program BEKERJA Kab. } \\
\text { Cirebon. } \\
\text { Tipe ukuran pengambilan gambar : } \\
\text { Long shot } \\
\text { Sudut pandang kamera : Eye level. } \\
\text { Pergerakan kamera : Pan right }\end{array}$ \\
\hline
\end{tabular}

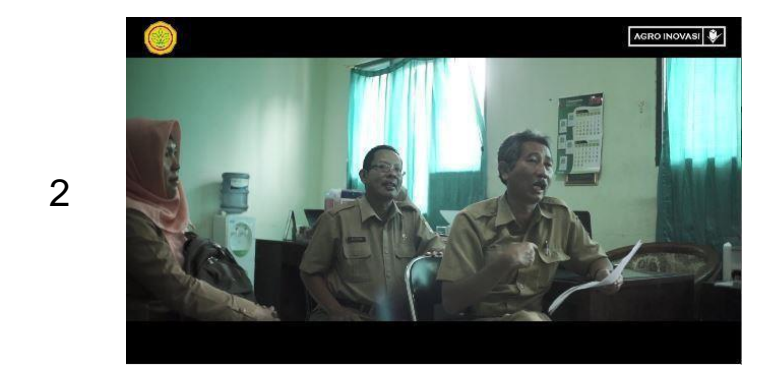

Rapat koordinasi dengan dinas pertanian Kabupaten Cirebon.

Tipe ukuran pengambilan gambar : Medium shot

Sudut pandang kamera : Eye level Pergerakan kamera : - 


\begin{tabular}{|c|c|c|}
\hline No & Adegan & Keterangan \\
\hline 3 & & $\begin{array}{l}\text { Rapat koordinasi dengan dinas Kab. } \\
\text { Cirebon. } \\
\text { Tipe ukuran pengambilan gambar : } \\
\text { Medium shot } \\
\text { Sudut pandang kamera : Eye level } \\
\text { Pergerakan kamera : - }\end{array}$ \\
\hline
\end{tabular}

3. Proses Penyuntingan

\section{- Menentukan Ukuran Video}

Pada proses pembuatan video ini ukuran video/frame size yang ditentukan berukuran 1920 pixels (horizontal/wide) x 1080 pixels (vertical/height) dengan menggunakan perbandingan tinggi : lebar (16:9) dan 59.94 frame per second (fps). Penentuan ini menyesuaikan pengaturan resolusi terbaik kamera penulis yaitu AVCHD 1080p agar video yang dihasilkan berkualitas tinggi, baik, dan tajam atau biasa disebut Full High Definition (FHD).

\section{- Mengimpor file}

Penulis mengimpor file logo Kementerian Pertanian dan Agro Inovasi dengan format .png sebagai identitas dari video tersebut, serta video outro yang dibuat oleh Penyuluh BBP2TP sebagai penutup dari video. Penulis juga menambahkan template intro sudah tersedia di Adobe Premiere Pro dan menambahkan audio instrumental untuk intro, musik Cinematic Inspiring, sunrise at paris van java, dan corporate kit yang sudah didapat pada tahap pengumpulan data.

\section{- Menambahkan efek khusus}

Pilihan efek khusus yang digunakan adalah lumetri color dan video transition. Pembuatan video ini dilakukan color grading untuk memperbaiki cahaya dan warna, serta memberikan suasana damai pada video dan menyesuaikan suasana backsound, pengaturan color grading ini menggunakan LUT (Look Up Table). Transisi yang digunakan yaitu Cross Dissolve, dan Dip To Black.

\section{- Menambahkan teks}

Penulis membuat intro sebagai judul video, lower third/name tag dan caption/subtitle. Proses pembuatan intro dan lower third menggunakan template yang tersedia dari menu essential graphic Adobe Premiere Pro CC 2018. Sedangkan, proses pembuatan caption/subtitle menggunakan fitur caption yang tersedia pada software. Typefaceyang digunakan untuk judul merupakan default dari template sehingga tidak dapat diubah, typeface untuk lower third yaitu coolvetica dan raleway, typeface untuk caption yaitu arial. 


\section{- Menyunting audio}

Audio yang terdapat dalam video ini terdiri dari tiga musik dan audio pembicaraan beberapa orang yang berisi informasi terkait kegiatan. Penyuntingan audio orang berbicara dikerjakan dengan Adobe Audition CC 2018, penyuntingan ini dilakukan untuk memperjelas vokal sesorang ketika berbicara. Efek yang dapat digunakan adalah vocal enhancer.

\section{- Rendering/Export}

Proses render video ini menghasilkan output video berdurasi 3 menit 34 detik dengan resolusi 1920 × 1080 pixel dan format mp4.

\section{Pengujian}

Pada tahap pengujian, hasil karya diperiksa kembali oleh pembimbing lapang dan Penyuluh BBP2TP dalam bentuk presentasi yang bertujuan agar video yang telah dibuat sesuai dengan materi. Terdapat revisi berupa saran pada penulisan caption/subtitle agar sesuai dengan Kamus Besar Bahasa Indonesia (KBBI).

\section{SIMPULAN}

Pembuatan Produk Multimedia Sebagai Media Informasi dan Dokumentasi Pertanian di BBP2TP dibuat dan dipublikasikan untuk memberi inovasi baru dalam penyampaian informasi digital. Poster lomba foto dan video yang diadakan oleh Kementerian Pertanian dipublikasikan ke media sosial Instagram BBP2TP. Video tutorial persiapan yang harus dilakukan ketika ayam KUB DOC akan datang, dipublikasikan saat kegiatan bimbingan teknis tentang program BEKERJA berlangsung diberbagai daerah di Indonesia. Video dokumenter dan testimoni masyarakat desa Bayalangu Kidul, Kabupaten Cirebon terhadap program BEKERJA dan video tutorial persiapan yang harus dilakukan ketika ayam KUB DOC akan datang, dipublikasikan ke digital banner BPTP News. Hasil karya yang dibuat masih terdapat beberapa kekurangan sehingga diperlukan saran dan pendapat dari berbagai pihak agar hasil karya dapat optimal.

\section{DAFTAR PUSTAKA}

Adobe. 2018. Adobe Audition User Guide: Effect reference [Internet]. [diakses 2019 Juli 1]. Tersedia pada: https://helpx.adobe.com/audition/using/noisereduction-restoration- effects.html\#adaptive_noise_reduction_effect.

Ariyus D. 2009. Keamanan Multimedia. Yogyakarta (ID): C.V ANDI OFFSET

Balai Besar Pengkajian Dan Pengembangan Teknologi Pertanian. 2008. Sejarah [Internet]. [diunduh 2019 April 18]. Tersedia pada : http://bbp2tp.litbang.pertanian.go.id/index.php/profil/sejarah.

Bonafix Nunnun. 2011. Videografi : Kamera dan Teknik Pengambilan Gambar [internet]. [diunduh 2019 Mei 20]; Volume 2(1). Tersedia pada: http://journal.binus.ac.id/index.php/Humaniora/article/view/4015/3172. 
Dafi Deff. 2016. Apa Itu LUT atau Look Up Table, Cara Membuat LUT dan Cara Menggunakan LUT [Internet]. [diakses 2019 Juli 10]. Tersedia pada: https://www.dafideff.com/2016/11/apa-itu-lut-atau-look-up-table.html

Enterprise J. 2018. Kitab Video Editing dan Efek Khusus. Jakarta (ID): PT. Elex Media Komputindo.

Enterprise J. 2019. Belajar Sendiri Adobe Premiere CC 2019. Jakarta (ID): PT. Elex Media Komputindo.

Hendratman H. 2017. The Magic Of Adobe Premiere Pro Revisi 3. Bandung (ID): Informatika Bandung.

Humaedah U, Medionovianto D, dkk. 2018. Pemeliharaan Intensif Ayam Lokal Unggul.

Bogor (ID): BBP2TP.

Kusnadi.2018. Dasar Desain Grafis Kurikulum 2013 Revisi. Tasikmalaya (ID): Edu Publisher.

Larasati A. 2018. Apa Itu Color Grading ? Yuk Simak Selengkapnya [Internet]. [diakses 2019 Juli 10]. Tersedia pada: https://idseducation.com/articles/apa-itu-color-grading- yuk-simakselengkapnya/

Lexi J. 2009. Metode Penelitian Kualitatif Edisi Revisi. Bandung (ID): Remaja Rosdakarya. 